\title{
Mapping Film Programming across Post-War Europe (1952)
}

\section{Arts and Media}

\author{
Thunnis van Oort \\ University of Amsterdam, Amsterdam, Netherlands \\ Oxford Brookes University, Oxford, UK \\ t.vanoort@uva.nl \\ Åsa Jernudd \\ Örebro University, Örebro, Sweden \\ asa.jernudd@oru.se \\ Kathleen Lotze \\ Oxford Brookes University, Oxford, UK \\ Hogeschool van Amsterdam, Amsterdam, Netherlands \\ lotze.kathleen@gmail.com \\ Clara Pafort-Overduin \\ Utrecht University, Utrecht, Netherlands \\ c.pafort-overduin@uu.nl \\ Daniël Biltereyst \\ Ghent University, Ghent, Belgium \\ daniel.biltereyst@ugent.be
}

Jaap Boter

Vrije Universiteit / University of Amsterdam, Amsterdam, Netherlands

jaap.boter@vu.nl

\section{Silvia Dibeltulo}

Oxford Brookes University, Oxford, UK

sdibeltulo@brookes.ac.uk 


\author{
Pier Ercole \\ De Montfort University, Leicester, UK \\ pier.ercole@dmu.ac.uk \\ Philippe Meers \\ University of Antwerp, Antwerp, Belgium \\ philippe.meers@uantwerpen.be \\ Terezia Porubcanska \\ Oxford Brookes University, Oxford, UK \\ University of Antwerp, Antwerp, Belgium \\ tereziaporubcanska@gmail.com
}

\title{
Daniela Treveri Gennari
}

Oxford Brookes University, Oxford, UK

dtreveri-gennari@brookes.ac.uk

\author{
Liesbeth Van de Vijver \\ Oxford Brookes University, Oxford, UK \\ Ghent University, Ghent, Belgium \\ liesbeth.vandevijver@ugent.be
}

\begin{abstract}
This data paper and the data collection from which it emerges aim to present a fully harmonized data set originating in several research projects on post-war cinema programming. The paper will reflect on the collection and structure of this aggregated data set, that consists of titles of feature films screened for public viewing in cinemas in the cities Bari (Italy), Antwerp and Ghent (Belgium), Gothenburg (Sweden), Leicester (United Kingdom) and Rotterdam (Netherlands) for the year 1952. As comparisons of movie-going patterns between European countries are still rare, this paper offers a model for constructing a data set which can be replicated, scaled up and used to compare, contextualize, and eventually theorize practices of cinema-going across countries at a global level.
\end{abstract}

\section{Keywords}

film programming - cinema - mid-sized city - Europe - comparative history 
- Related data set "Film programming Antwerp Bari Ghent Gothenburg Leicester Rotterdam 1952" with DOI https://www.doi.org/10.17026/dans-zed2hg2 in repository "DANs"

- See the showcase of the data in the Exhibit of Datasets: https://www.dans datajournal.nl/rdp/exhibit.html? showcase $=$ oort202ob

\section{Introduction}

The rise of the cinema as a cultural industry since the dawn of the twentieth century and its endurance into the twenty-first has had an abiding impact on the social, cultural and economic infrastructures of modernizing societies. Questions that address the wider contexts of the production, distribution and - especially - consumption of film form the groundwork for a growing field called New Cinema History (Biltereyst, Maltby, \& Meers, 2019; Maltby, Biltereyst, \& Meers, 2011).The increasing interest in the specific circumstances in which films were circulated and watched historically has resulted in a proliferation of often local or regional case studies. A key challenge facing this field of research is to integrate the diversity of local microhistorical studies into interpretative frameworks at the meso level (Maltby, 2011). One promising way to attain a higher level of generalisation is transnational comparative research. Comparisons of movie-going patterns between European countries are virtually uncharted territory, in particular for the post-wwII era, and the penetration of the film exhibition market has shown remarkable differences between European countries (Convents \& Dibbets, 2008; Garncarz, 2015; van Oort, 2016).

The development of New Cinema History has been stimulated by the advancement of new digital tools, sources and methods that gained momentum in the humanities after 2000 (Noordegraaf, Lotze, \& Boter, 2018). This has resulted in a broad assortment of digital data collections for historical cinema studies. In theory, these data sets would allow for larger, transnational comparisons, addressing the aforementioned problem of the fragmentation of the field. In practice, however, differences in data formats and types used in the various collections have impeded actual comparative analysis (cf. Verhoeven, 2016). Digital data and tools allow for an unprecedented extension of quantitative analyses of cinema markets within and across national borders (Dibbets, 2010), yet these opportunities have not been exploited apart from in a handful of small-scale (pilot) studies (Biltereyst \& Meers, 2016; Boter \& Pafort-Overduin, 2009; Sedgwick, Pafort-Overduin, \& Boter, 2012; van Oort \& Pafort-Overduin, 2018). One of the most recent research projects to 
tackle this challenge is European Cinema Audiences. Entangled Histories and Shared Memories (AHCR, 2018-2021), which aims at comparing the experiences of cinema-going in seven European cities in the 1950s (https://www.europe ancinemaaudiences.org).

This data paper and the data collection from which it stems, result from a partly project-based and partly informal collegial collaboration that includes scholars from five European countries. To solve the issues of fragmentation and data interoperability described above, we decided to start by locating common ground between our various data sets and research interests. The joint collection consists of data of feature films screened for public viewing in cinemas in the cities Bari (Italy), Antwerp and Ghent (Belgium), Gothenburg (Sweden), Leicester (United Kingdom) and Rotterdam (Netherlands) for the year 1952. This paper aims to present this harmonized data set originating in several research projects covering six European mid-sized cities and reflect on the collection and structure of this aggregated data set, and its potential use in addressing relevant research questions.

Our data set offers a model to collect information on historical film cultures which can be replicated, scaled up and used to compare, contextualize, and eventually theorize practices of cinema-going across different countries at a global level.

Both individually and with each other, the various tables, as described below, can provide insights into the size, structure and functioning of the cinema markets in the different cities and serve as a starting point for research into further economic, social or cultural explanations. For example, the comparison of the number of inhabitants per cinema seat can indicate the importance that is attached to the cinema and cinema-going in different societies (PafortOverduin, Lotze, Jernudd, \& van Oort, in press). Alternatively, comparing how ownership of cinemas was organised (to which extent did horizontal or vertical integration occur) can provide insights into the differences in the economic strength of the sector (Pafort-Overduin et al., 2017). The data can also serve as the basis for a network analysis that can be used to compare distribution patterns and identify similarities or differences with the known dominant models of distribution and exhibition (Pafort-Overduin et al., in press). The results of such comparative analyses can serve as an entry point for questions that can be answered through more traditional historical research and cultural analysis.

Programming information (which film was shown where and for how long) can be analysed using the POPSTAT index (a formula developed by John Sedgwick to determine the relative popularity of films in the absence of box-office information; see Sedgwick, \& Pokorny, 2005) to identify differences and similarities in film preferences between, as well as within, different cities. Shared 
and diverging film preferences can point to different cultural values and can form the basis for research into understanding cultural similarities and differences (e.g. Sedgwick, Miskell, \& Nicoli, 2019).

\section{Academic Context}

The film programming data set for $195^{2}$ assembled for this article was originally collected for different projects that have been ongoing at different points in time starting already in the late 1970 os by Karel Dibbets, which formed the basis of the Cinema Context database later and from which parts of the data set for Rotterdam was extracted (Dibbets, 1980). The Cinema Context database pioneered the practice of collecting historical data for cinema exhibition and contains records of films, cinemas, film industry professionals and companies in the Netherlands from the 1890 s to our day (http://www.cinemacontext.nl; see also Noordegraaf et al., 2018; van Oort \& Noordegraaf, 2020). The Rotterdam data set was subsequently supplemented with programming data collected for the DIGIFIL project at the University of Amsterdam (CLARIAH, 2018; see https://www.clariah.nl/). The Antwerp and Ghent data sets were constructed within the Enlightened City research project (The Flemish Research Foundation FWO, 2005-2008), the Gent Kinemastad research project (Ghent University Research Council воF, 2009-2013) and the Antwerpen Kinemastad project (Antwerp University Research Council воғ, 2009-2013).

The Leicester and Bari data sets were initially collected for the project Mapping European Cinema: A Comparative Project on Cinema-going Experiences in the 1950s (British Academy / Leverhulme fund, 2016-2017). The aim of the Mapping European Cinema project was a comparative analysis of cinema programming and oral history data in 1950s Great Britain, Italy and Belgium, in order to explore programming patterns and cinema-going experiences in cities of similar size and film exhibition structure but of very different film cultures. The project was successfully expanded into a larger study (European Cinema Audiences, see above) which has added Rotterdam (The Netherlands), Brno (Czech Republic), Magdeburg (Germany) and Gothenburg (Sweden) to the comparative analysis. Finally, the Gothenburg data set was put together in the context of a series of international scholarly meetings on the interdisciplinary study of film culture, film economics and human geography (European Research on the Historical Experience of Cinema Going, Riksbankens Jubileumsfond, 2016-2017).

Harmonising the methodology of the data collection across all cities was aided by the fact that some projects are interconnected and have involved the same researchers. The collection was already put to use while being compiled: 


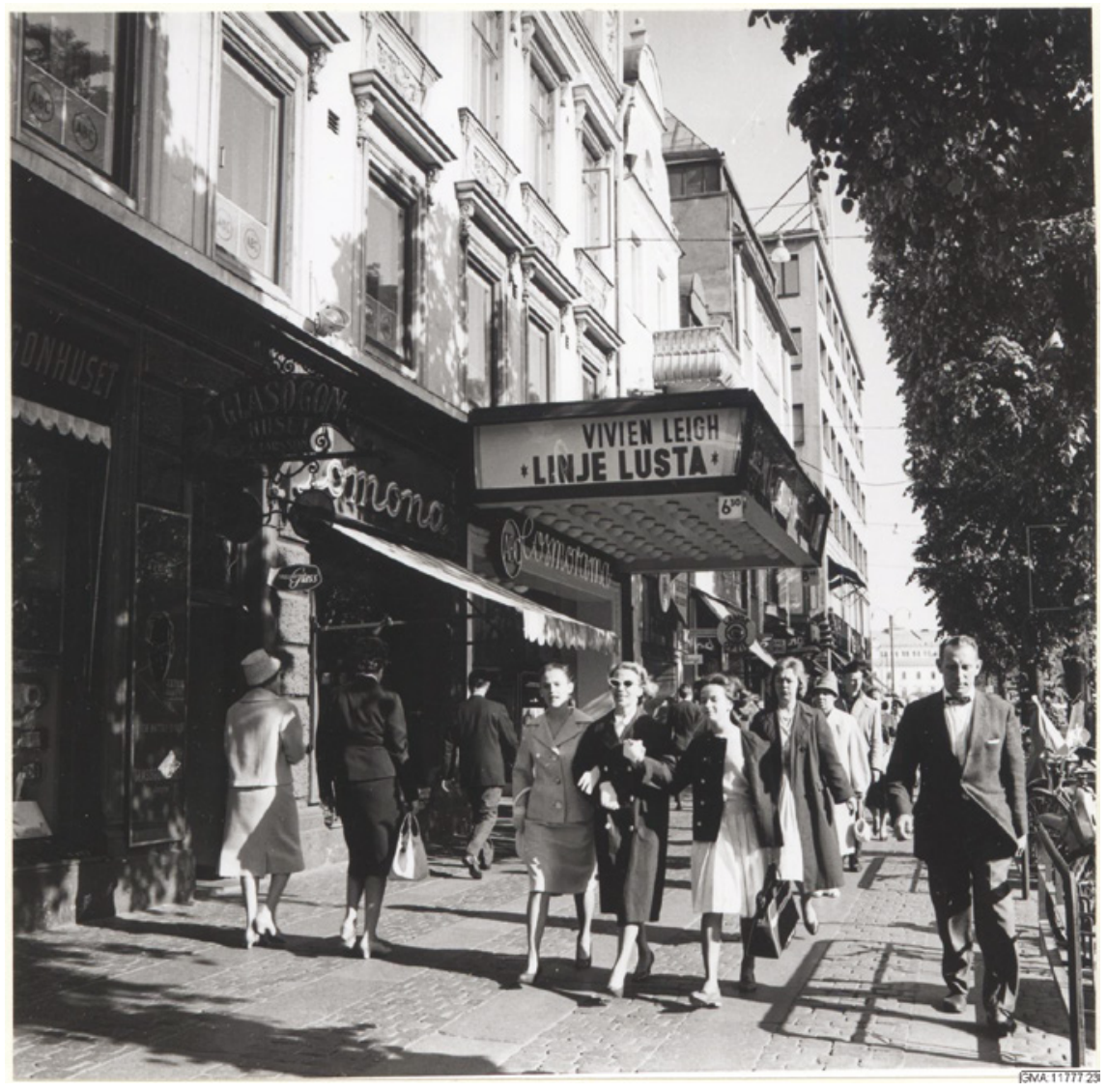

FIGURE 1 The Cosmorama cinema in Gothenburg from 1952 PHOTO BY ERIK LILJEROTH. GÖTEBORGS STADSMUSEUM.

parts of it have been explored by researchers as well as analysed comparatively for paper presentations at conferences (Pafort-Overduin, 2017; Pafort-Overduin et al., 2017; Pafort-Overduin et al., in press).

3. Data Set

- Film programming Antwerp Bari Ghent Gothenburg Leicester Rotterdam $195^{2}$ deposited at DANS - DoI:https://www.doi.org/10.17026/dans-zed -2 hg2

- Temporal coverage: $195^{2}$ 
In this section, we will first briefly describe the structure of the SQL database. Then, we will discuss decisions made in the process of collecting the data.

\subsection{SQL Database}

The various data sets collected per city have been integrated into one single SQL database. The database consists of eight tables that are briefly described in Table 1. Most fields are rather straightforward and self-explanatory, but a further explanation can be found in the following sections on the cities and cinemas and the screenings.

TABLE 1 The nine tables of the SQL database

\begin{tabular}{|c|c|c|}
\hline Table & Field name & Description \\
\hline \multirow[t]{14}{*}{ cinemas } & id & Unique identifier \\
\hline & name & Name of cinema \\
\hline & city & City including surrounding municipalities \\
\hline & street & Street name in use in $195^{2}$ \\
\hline & municipality & Name of municipality \\
\hline & seats & $\begin{array}{l}\text { Number of seats in } 195^{2} \text { (or other closest available } \\
\text { year) }\end{array}$ \\
\hline & x_epsg_4326 & Y coordinate of the location of cinema (wGs 84) \\
\hline & y_epsg_4326 & X coordinate of the location of cinema (wGs 84) \\
\hline & owner & $\begin{array}{l}\text { Name of owner/manager of cinema (natural } \\
\text { person) }\end{array}$ \\
\hline & company & Name of owner/manager of cinema (company) \\
\hline & exhibitor & $\begin{array}{l}\text { Name of either natural person or company/chain } \\
\text { involved in operating the cinema (sometimes partly } \\
\text { overlapping with owner or company) }\end{array}$ \\
\hline & opening_year & Year when cinema was opened \\
\hline & closing_year & Year when cinema was closed \\
\hline & notes & Free text field for comments \\
\hline \multirow[t]{2}{*}{ cities } & id & Unique identifier \\
\hline & name & City name (including surrounding municipalities) \\
\hline directors & id & $\begin{array}{l}\text { Unique identifier for the director as listed in IMDb } \\
\text { (or other repository) }\end{array}$ \\
\hline
\end{tabular}


TABLE 1 The nine tables of the SQL database (cont.)

Table Field name Description

name Name of the director as listed in IMDb (or other repository)

directors2films film_id

film2countries filmid country

films

$\begin{array}{ll}\text { film_titles } & \begin{array}{l}\text { film_id } \\ \text { title }\end{array} \\ \text { screenings } & \begin{array}{l}\text { week } \\ \text { date }\end{array} \\ & \begin{array}{l}\text { source_title } \\ \text { comment } \\ \text { cinema }\end{array}\end{array}$

city

film_id
Unique identifier for the film as listed in IMDb (or other repository)

Identifier for the director as listed in IMDb (or other repository)

Unique identifier

Country or countries of production. IMDb defines the country of a title as the place or places where the production companies for that title are based, and therefore where the financing originated

Unique identifier

primaryTitle Primary title as used in IMDb (or other repository)

startYear Year of earliest public release (according to IMDb or alternative source)

runTime- $\quad$ Runtime of the film in minutes (according to the Minutes IMDb)

Unique identifier

Alternative title

Week of the year in which the film was screened Day of screening (Bari, Ghent, Gothenburg and Leicester) or first day of screening week (Antwerp, Rotterdam)

Title as advertised in the source Free text field for comments on the programme Identifier of the cinema where the film was screened on that date Identifier of the city where the film was screened on that date Identifier of the film screened on that date and place 


\subsection{Cities and Cinemas}

The choice of cities for which the film programming data was collected, was partly a result of the focus and research intentions of earlier projects; these were cities in Europe for which cooperating researchers had begun to collect programming and cinema data for the period covered (see above). However, the six cities do have important features in common which motivate their inclusion in the data set and can, to a degree, stabilize the framework for comparisons. With Bari in Italy as an exception, they are situated in Northern Europe. They are all second-tier cities, i.e. cities that are "in the middle of the urban system", between the capital cities which have special economic, social and cultural status and the many smaller localities (ESPON \& European Institute of Urban Affairs, 2012, p. 8). There are often several second-tier cities in any one country and they can vary in size which is also the case with the cities in our comparison. Connolly (2008) and Hodos (2011) have argued that secondtier cities have a specific historical trajectory that is under-researched. Keeping in mind that 1950s European cities were more compact and less sprawled than they are today (European Environment Agency, 2006), "a relatively dense mesh of medium-sized, historically stable urban centers" has been described as a defining feature of the European urban system, encompassing most of the European population (Cardoso, \& Meijers, 2016, p. 996-997). The cities selected for this project had a population of around 300,000 in the early 1950s, except for Rotterdam and Antwerp, which counted over half a million inhabitants. While the three industrial harbour cities of Antwerp, Gothenburg and Rotterdam are among the larger cities in their respective countries, the cities of Bari (also with a sea harbour), Ghent and Leicester are relatively smaller.

For each of the six cities, data has been compiled on cinemas that announced their film programs in daily newspapers. The name and location of the venues were often available in advertisements for film screenings in local newspapers. The newspapers that were mainly used as primary sources are Göteborgs Handels- och Sjöfartstidning, Het Vrije Volk, De Telegraaf, Gazet van Antwerpen, De Gentenaar, Vooruit, and La Gazzetta del Mezzogiorno. As the aim has been to be as exhaustive as possible, multiple sources were used to obtain a full picture of the exhibition sector. Therefore, for some cities, the data was complemented and cross-checked with city directories, local authority listings, yearbooks and trade journals. ${ }^{1}$

1 For Antwerp information was found, for example, in Annuaire Général du Spectacle en Belgique (1956), Belgische Syndicale Kamer van Cinematografie, (1953), Weekblad Cinema; for Ghent: Union Belge des Annonceurs (1954); Annuaire Général du Spectacle en Belgique (1956). For Gothenburg, the newspaper findings were checked against listings held by the national trade organisation for the film exhibition sector (Filmägarnas kontrollförening, 1956). 
The data that was collected about each cinema consisted of the name of the venue, its street address and geographical coordinates. Furthermore, the data set includes the number of seats, depending on the availability of the data. In some cases only the seating capacity of earlier or later years was known from the sources; this number could change over time if the auditorium was refurbished or renovated. Also, whenever available, information was collected on the persons and companies involved in operating the cinema, such as owners or managers, and also the years of the opening and closing of the cinemas are available in the data set.

The 162 cinemas included in the data set are situated within the city boundaries as defined through two interrelated aspects: as a central place performing comprehensive services for its surrounding area and with public transportation that links its spaces of production, settlement and services (Harris \& Ullman, 2005).

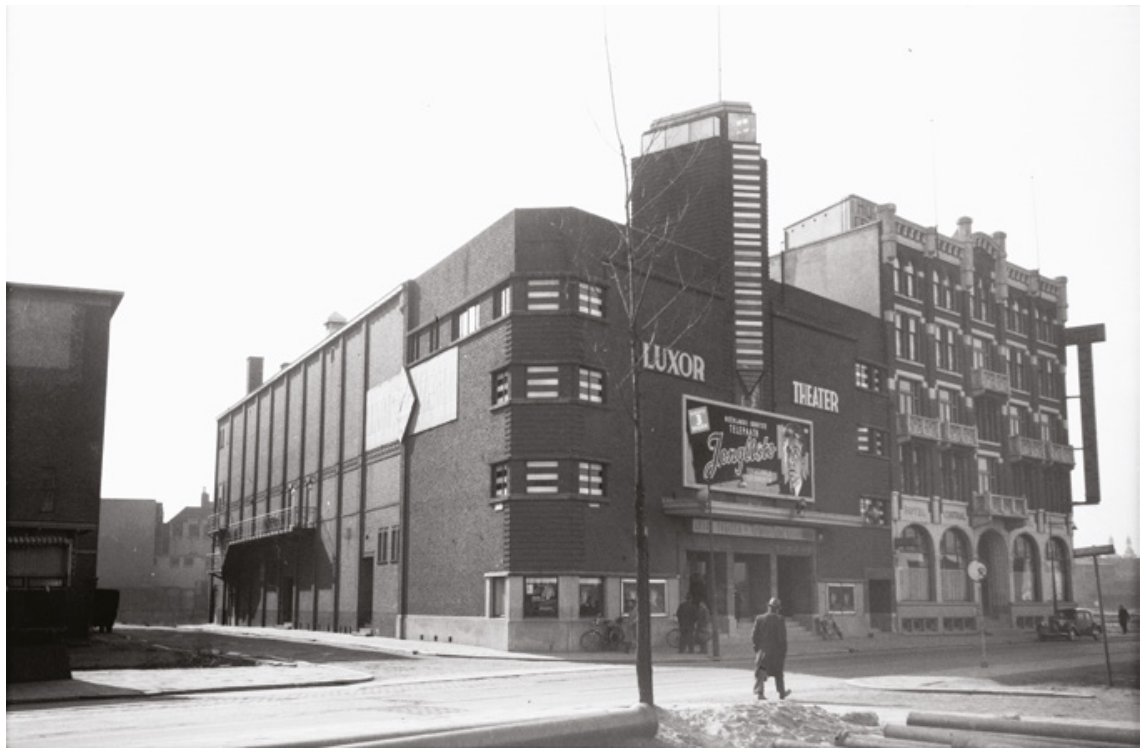

FIGURE 2 View of the Kruiskade and corner of the Nieuwe Kerkstraat in Rotterdam, showing the Luxor cinema, that had survived the 1940 bombardment of Rotterdam

PHOTO BY GERARD ROOS, 1946. CITY ARCHIVE ROTTERDAM.

Information about the venues' seating capacity was not as readily available. For Gothenburg, this was listed in the mentioned trade book. For Rotterdam, Cinema Context was used for information on the cinemas (van Oort \& Noordegraaf, 2020). For Bari, the Annuario del Cinema (1951) was also used. 
The process of linking the various data sets of cinema venues engendered a discussion on the ontology of the cinema theatre: should its definition be limited to purpose-built cinemas or should it include multipurpose venues in which public cinema screenings took place alongside other activities? Furthermore, should cinemas that offered screenings on an infrequent and irregular basis be included? To resolve these issues, a cinema in this data set is defined as a venue where $35 \mathrm{~mm}$ and $16 \mathrm{~mm}$ feature films were screened that were announced to and accessible by a general audience. In the cases where a cinema used the same venue name for exhibition on several screens, sometimes in a different location, it is noted as a second venue (this occurred in Bari, where during summer months some cinemas would conduct open-air screenings at a different location).

\section{3. $\quad$ Film Programming and Film Titles}

The Screening table in the database combines a date with a venue and film title. For the sample year 1952, we have collected 58,991 records for film programmes in the six selected cities. The amount of film programming records varies per city, depending on the number of cinemas, the frequency of changes of the film programs, but also on the availability and characteristics of the sources used. For most cities, the film programming data originates in film listings which were published in local newspapers. ${ }^{2}$ These listings were usually published at least on a weekly and for some cities even on a daily basis (in Göteborgs Handels- och Sjöfartstidning and in La Gazzetta del Mezzogiorno in Bari cinema screenings were advertised six days a week). For some cinemas no programming data is available. However, those cinemas are included in the cinema table to allow for a more complete mapping of the cinema culture.

The temporal unit for screenings differs, for various reasons. Some sources are more detailed than others, in listing screening information either on a weekly or daily basis. Moreover, the exhibition and distribution systems differed from country to country: in Belgium and the Netherlands, weekly changes of film programmes were prevalent in most cinemas, while in Italy, daily programme changes were more common. While for Bari, Ghent, Gothenburg and Leicester film programming data is available per day, for Antwerp and

2 In the case of Antwerp, part of the film programming data was based on the business ledgers of a key player in the local exhibition market, Georges Heylen (see Lotze \& Meers, 2013). The ledgers contain weekly overviews of the films screened in a selection of cinemas in Antwerp per cinema, including the names of the distributors per film. As not all cinemas were included in the ledgers, the data set was complemented with information from the weekly film listings in the local newspaper at a later stage. 
Rotterdam they are mostly available on a weekly basis. ${ }^{3}$ For the Rotterdam data, the information on weekly screenings has been transposed to daily screenings. For Antwerp, only weekly screening dates are currently available. This is something to be kept in mind for future use of the data for calculating the relative success of particular films.

The most labour-intensive job has been the identification of all film titles included in the film programming set. Different films, or different versions of a film, were distributed under the same title and the other way around: a single film could be distributed under a variety of alternative or translated titles. When identification was questionable, additional contextual information provided in advertisements or reviews in the sources were helpful. After the integration of the various datasets, another round of title disambiguation was completed.

In order to establish a list of unique film titles, where possible, a unique identifier from the Internet Movie Database (IMDb) was collected, since this is by far the most comprehensive online database for this subject that is available. ${ }^{4}$ For those film titles not listed in IMDb, - in most cases nonEnglish-language films - alternatives were used, such as Filmportal (German), MovieMeter (Dutch), Rivista del Cinematografo (Italian) or the Swedish book series Wredlund and Lindfors (1979-1993). Only feature films were included in the database (we agreed on a threshold of a minimum film length of $5^{0}$ minutes, corresponding to 4500 feet / 1400 meters). Newsreels or short films screened before the main feature, for example, were excluded. This decision was primarily based on the fact that shorter items, including newsreels, cartoons, et cetera, were advertised only incidentally and are highly problematic to identify. Unidentified films received a special identifier JACK\#.

The variables in the Film table can be used for several analytical purposes. Year of the first release allows for analyses regarding the lifespan of a film in cinemas. The relative age of films programmed can help with establishing profiles of cinemas: whether they screened premieres or recent films, or later runs. The country/countries of production can be used to identify cinemas with a

3 For Gothenburg, the number of daily screenings is stored; often, films would be screened two or three times per day. For the other cities, a maximum of one screening per day is recorded in the database.

4 Although IMDb is an open content database, the main data provided on this website can be considered relatively stable, as they underlie strict submission guidelines and self-correction by its users. See https://help.imdb.com/article/contribution/contribution-information/submission-guides-a-z/GWBAHKgSAMVR3DP5?ref_=helpsrall\#; last accessed 11 October 2018. For critical reviews on IMDb, see, for example, Wassermann et al. (2015). 


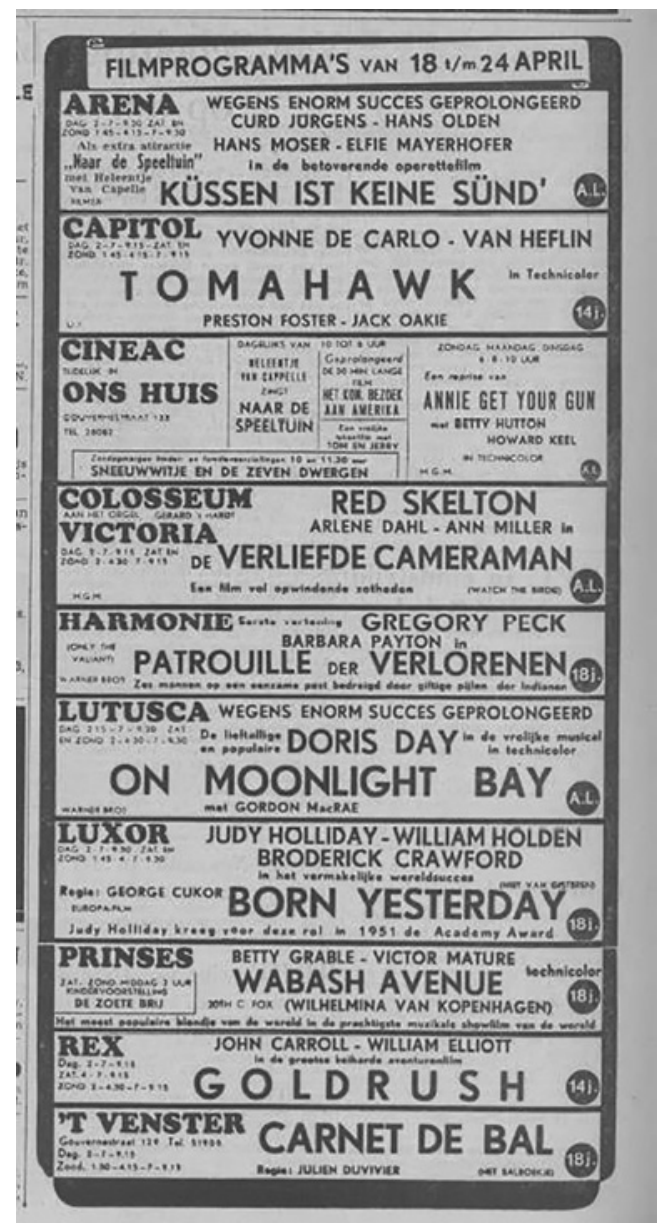

FIGURE 3

Example of a Rotterdam film listing. Algemeen Dagblad, 17 April, $195^{2}$ HTTPS://RESOLVER.KB.NL/RESOLVE ?URN=MMKB19:000326091

profile of screening films from a specific country of origin and analyse cultural exchange between countries.

\section{Concluding Remarks}

This kind of collective data collection presents researchers with a set of practical challenges such as data sharing, working together across different institutions and nations, as well as limitations in terms of access to available sources, and compatibility of data and software. The challenges are also epistemological, as tool criticism, standardisation and transparency of the data suppliers are essential for users to meet their specific research question. 
In practical terms, we have experienced that building a dataset such as the one presented here requires a constant eye for detail and a considerable amount of time must be set aside for close consultation on the procedures involved. (Our international collaboration has indeed been greatly facilitated by the availability of online video conference calls.) While it is necessary to abide by agreements made about particular procedures as the work progresses - in the ambition to standardise the data set and create interoperability between its parts composed of various provenience - it is equally important to demonstrate adaptability. Throughout the process, we became increasingly aware of the importance of constantly checking and calibrating definitions, structure, as well as methods of data collection. Fine-tuning is necessary because there can be great variation in the forms in which data occurs; it is impossible to determine in advance exactly how each item will be found and defined in different national contexts. One example in our data set concerns the screening period of the films. Data on this is available either on a daily or weekly basis in the various cities, due to variation in the way this data is presented in the sources and also due to different (national) film distribution practices. Another example of asymmetrical information retrieval from similar historical sources across the cities in our corpus concerns the national opening date of a film. This is important information. To assess audience taste, for example, it is necessary to know the opening date of a film to determine whether a film that received few screenings was screened for the first time or in a series of subsequent screenings ('runs') several weeks or even months after the (national) premiere. Yet we decided to exclude the opening date from our data set because we could not find this date for all films in each city.

Local and regional historical case studies of distribution and exhibition of cinema have revealed a great diversity of practices, and will likely continue to flourish given their relative feasibility not only in terms of research design and procedure but also in light of opportunities for research funding. However, to be able to take steps toward building interpretative frameworks at the meso level (Maltby, 2011) an aggregation of larger data sets is necessary. With cinemas and film screenings in several European cities in a particular year (1952) at its core, the aggregated data set that is described in this article can facilitate transnational comparative research that in turn can aspire to higher levels of generalisation than would be possible when working with fragmented data from various local contexts. We have intended to detail the methodological challenges involved in aggregating a historical cinema data set that maps film programming across cities in Europe in 1952. We hope the article and its data set can be valuable to future scholars within the field of New Cinema History 
research as well as to researchers of other cultural industries for cross-sectoral comparisons.

\section{Acknowledgements}

Teresa Muzzatti for the Bari data set; Allissandra Nogitsune for work on the Gothenburg data set; Ivan Kisjes for the integration of the various subsets.

\section{References}

Annuaire Général du Spectacle en Belgique 1956-. Spectacles, cinéma, musique, radio, television. (1956). Brussels: Editions l'Epoque.

Associazione Generale Italiana dello Spettacolo (AGIS). (1950-1951). Annuario del Cinema. Rome.

Belgische Syndicale Kamer van Cinematografie / Chambre Syndicale Belge de la Cinematographie / Belgian Syndicate of Cinematography. (1953). Liste des salles $35 \mathrm{~mm}$ existant à la date du zo juin 1952 - mise à jour au 15 mai 1953. Brussels.

Biltereyst, D., Maltby, R., \& Meers, P. (Eds.). (2019). The Routledge companion to New Cinema History. New York: Routledge.

Biltereyst, D., \& Meers, P. (2016). New Cinema History and the comparative mode: Reflections on comparing historical cinema cultures, Alphaville, $11,13^{-32}$.

Boter, J., \& Pafort-Overduin, C. (2009). Compartmentalisation and its influence on film distribution and exhibition in the Netherlands, 1934-1936. In M. Ross, M. Grauer \& B. Freisleben (Eds.). Digital tools in media studies. Analysis and research. An overview (pp. 55-68). Bielefeld: Transcript.

Cardoso, R. V., \& Meijers, E. J. (2016). Contrasts between first-tier and second-tier cities in Europe: a functional perspective. European Planning Studies, 24(5), 996-1015. https://www.doi.org/10.1080/09654313.2015.1120708.

Connolly, J. J. (2008). Decentering urban history: Peripheral cities in the modern world. Journal of Urban History, 35(1), 3-14. https://www.doi.org/10.1177\%2Foo 96144208320732 .

Convents, G., \& Dibbets, K. (2008). Verschiedene Welten. Kinokultur in Brüssel und in Amsterdam 1905-1930. In C. Müller \& H. Segeberg (Eds.), Kinoöffentlichkeit (18951920). Entstehung, Etablierung, Differenzierung / Cinema's public sphere (1895-1920). Emergence, settlement, differentiation (pp. 150-156). Marburg: Schüren.

Dibbets, K. (1980). Bioscoopketens in Nederland. Ekonomiese koncentratie en geografiese spreiding van een bedrijfstak, 1928-1977 (MA thesis). University of Amsterdam: Amsterdam. 
Dibbets, K. (2010). Cinema Context and the genes of film history. New Review of Film and Television Studies, 8(3), 331-342.

ESPON \& European Institute of Urban Affairs. (2012). SGPTD - Second-tier cities and territorial development in Europe: Performance, policies and prospects. Liverpool: John Moores University.

European Environment Agency. (2006). Urban sprawl in Europe. The ignored challenge (EEA Report 10). Copenhagen. https://www.eea.europa.eu/publications/eea_report _2006_10/eea_report_10_2006.pdf/view.

Filmägarnas kontrollförening (1956). Sveriges biografer: förteckning över biografer och biografägare : utg. på grundval av material från Filmägarnas kontrollförening u.p.a. Stockholm: Spectator.

Garncarz, J. (2015). Wechselnde Vorlieben. Über die Filmpräferenzen der Europäer, 18961939. Frankfurt am Main/Basel: Stroemfeld.

Harris, C. D., \& Ullman, E. L. (2005). The nature of cities. In N. R. Fyfe \& J. T. Kenny (Eds.), The Urban Geography Reader (pp. 46-55). New York: Routledge.

Hodos, J. (2011). Second cities: Globalization and local politics in Manchester and Philadelphia. Philadelphia, PA: Temple University Press.

Lotze, K., \& Meers, P. (2013). They don't need me in heaven... there are no cinemas there, ye know: Cinema culture in Antwerp (Belgium) and the empire of Georges Heylen, 1945-75. In K. Aveyard \& A. Moran (Eds.), Watching films: New perspectives on movie-going, exhibition and reception (pp. 223-244). Bristol/Chicago: Intellect Books.

Maltby, R. (2011). New Cinema Histories. In R. Maltby, D. Biltereyst \& P. Meers (Eds.), Explorations in new cinema history: Approaches and case studies (pp. 1-40). Chichester, UK: Wiley-Blackwell.

Maltby, R., Biltereyst, D., \& Meers, P. (Eds.). (2011). Explorations in New Cinema History: Approaches and case studies. Chichester, UK: Wiley-Blackwell.

Noordegraaf, J., Lotze, K., \& Boter, J. (2018). Writing cinema histories with digital databases: The case of Cinema Context, Tijdschrift voor mediageschiedenis / Journal for Media History 21(2): 106-126.

Pafort-Overduin, C. (2017, November). Cinematic Foreignness, Film Popularity and Audiences. Multivoicedness in European Cinema. Representation, Industry, Politics. Presentation at 2017 ECREA Film Studies Section Conference, Cork, Ireland.

Pafort-Overduin, C., Lotze, K., Jernudd, A., van de Vijver, L., Treveri Gennari, D., \& van Oort, T. (2017, June). Shared pleasures? Comparing film practices in European harbor cities: Antwerp, Bari, Gothenburg and Rotterdam. HoMER conference. Panel at HoMER conference Circuits of cinema: Histories of movie and media distribution, Toronto.

Pafort-Overduin, C., Lotze, K., Jernudd, A., \& van Oort, T. (in press). Moving films: visualizing film flow in four European cities in 1952. TMG - Journal for Media History, 23(1). 
Sedgwick, J., Miskell, P., \& Nicoli, M. (2019). The market for films in postwar Italy: Evidence for both national and regional patterns of taste. Enterprise \& Society, 20(1), 199-228. https://www.doi.org/10.1017/eso.2018.22.

Sedgwick, J., Pafort-Overduin, C., \& Boter, J. (2012). Explanations for the restrained development of the Dutch cinema market in the 1930s. Enterprise \& Society, 13(3), 634-671.

Sedgwick, J., \& Pokorny, M. (2005). The film business in the United States and Britain during the 1930s. The Economic History Review, 58(1), 79-112.

Union Belge des Annonceurs. (1954). Répertoire publicitaire du cinéma Belge. Brussels. van Oort, T. (2016). Industrial organization of film exhibitors in the Low Countries: comparing the Netherlands and Belgium, 1945-1960. Historical Journal of Film, Radio and Television, 37(3), 475-498. https://www.doi.org/10.1080/01439685.2016.115 7294.

van Oort, T., \& Noordegraaf, J. (2020). The Cinema Context database on film exhibition and distribution in the Netherlands: A critical guide. Research Data Journal for the Humanities and Social Sciences, 5(2), 91-108, doi:10.1163/24523666-00502008.

van Oort, T., \& Pafort-Overduin, C. (2018). New Cinema History in the Low Countries and beyond: An introduction, TMG - Journal for Media History, 21(1), 10-18.

Verhoeven, D. (2016). Show me the history! Big data goes to the movies. In C. R. Acland \& E. Hoyt (Eds.), The arclight guidebook to media history and the digital humanities (pp. 165-183). Sussex, UK: Reframe Books.

Wasserman, M., Mukherjee, S., Scott, K., Zeng, X. H. T., Radicchi, F., \& Amaral, L. A. N. (2015). Correlations between user voting data, budget, and box office for films in the Internet Movie Database. Journal of the Association for Information Science and Technology, 66(4), 858-868. Retrieved from https://onlinelibrary.wiley.com/doi/ full/10.1002/asi.23213.

Wredlund, B., \& Lindfors, R. (1979-1993). Långfilm i Sverige 1910-1989. 8 vols. Stockholm: Proprius.

\section{Newspapers, Magazines}

Gazet van Antwerpen

La Gazzetta del Mezzogiorno

De Gentenaar

Göteborgs Handels- och Sjöfartstidning

De Telegraaf

Het Vrije Volk

Vooruit

Weekblad Cinema 